\title{
Influence of temperature on the adhesion of fibre reinforced polymers to timber surface
}

\author{
Influência da temperatura na aderência à madeira de \\ polímeros reforçados com fibras
}

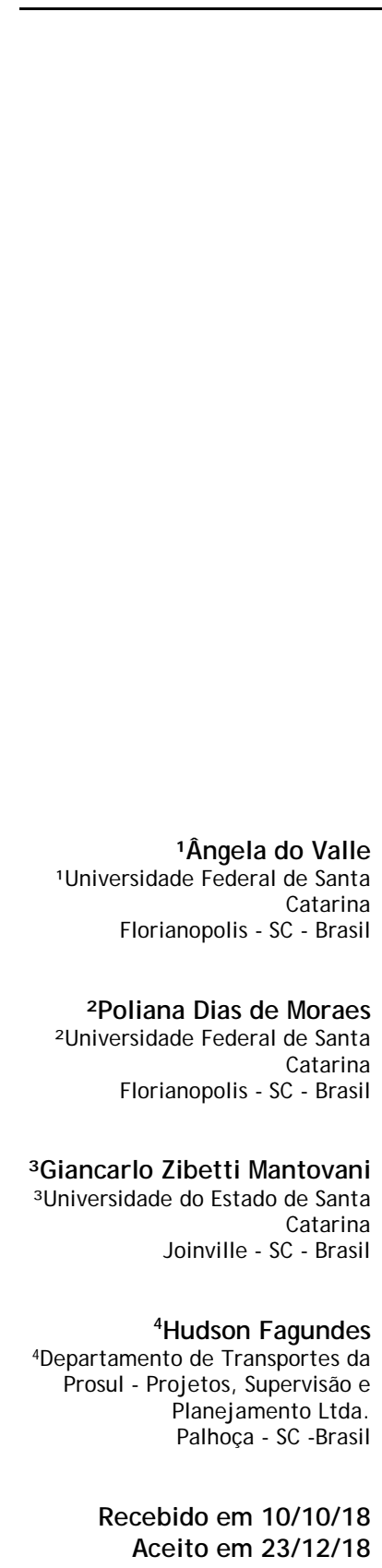

\section{Ângela do Valle \\ Poliana Dias de Moraes \\ Giancarlo Zibetti Mantovani \\ Hudson Fagundes}

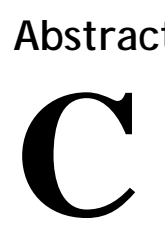

arbon and glass fibre reinforced polymer composites are being increasingly used in timber structures, where they can be exposed to harsh temperature conditions. In order to be properly used, information is needed on their adhesion to the substrate. The objective of this research is to evaluate the influence of temperatures between 20 and $80^{\circ} \mathrm{C}$ on the adhesion of these reinforcements to the wood. The shear test of adhesive line and pull-off test of the reinforcement from wood surface were carried out using specimens made of Pinus spp. The results demonstrated that temperature causes the nonlinear reduction of the reinforcement adhesion. The specimens exposed to a temperature of $80{ }^{\circ} \mathrm{C}$ presented residual bond strength means of $34 \%$ and $20 \%$ of the mean strength at room temperature for CFRP and for GFRP, respectively. Caution in using the applied resins is required due to the presented behaviour even in the service temperature range specified by the manufacturers.

Keywords: Bonding. Polymeric adhesives. Temperature. Timber. Structural reinforcement.

\section{Resumo}

Os reforços de compósitos poliméricos com fibras de carbono (CFRP) e de vidro (GFRP) têm sido largamente usados em estruturas de madeira, onde eles podem estar expostos a condições adversas de temperatura. Para serem usados adequadamente, são necessárias informações sobre a sua adesão ao substrato. $O$ objetivo desta pesquisa é avaliar a influência de temperaturas entre 20 e $80^{\circ} \mathrm{C}$ na adesão à madeira destes reforços. Testes de cisalhamento na linha de cola e de pull-off do reforço foram realizados em corpos de prova de madeira de Pinus spp. Os resultados mostraram que o aumento da temperatura provoca a redução não linear da adesão dos reforços. As resistências residuais médias de colagem dos corpos de prova reforçados, expostos à temperatura de $80{ }^{\circ} \mathrm{C}$, foram iguais a $34 \%$ e $20 \%$ dos valores médios obtidos à temperatura ambiente, para reforços com fibras de carbono (CFRP) e com fibras de vidro (GFRP), respectivamente. É recomendada cautela no uso das resinas testadas, mesmo para a faixa de temperatura de serviço especificada pelos fabricantes, devido ao comportamento observado.

Palavras-chave: Adesão. Adesivos poliméricos. Temperatura. Madeira. Reforço estrutural.

VALLE, A. do; MORAES, P. D. de; MANTOVANI, G. Z.; FAGUNDES, H. Influence of temperature on the adhesion of fibre 25 reinforced polymers to timber surface. Ambiente Construído, Porto Alegre, v. 19, n. 3, p. 25-38, jul./ set. 2019. ISSN 1678-8621 Associação Nacional de Tecnologia do Ambiente Construído. 


\section{Introduction}

Changes in timber structures over their useful life span are normal, in order to adapt to the new building functions and for the replacement of constructive elements due to deterioration by the weathering action (CRUZ, 2001). The rehabilitation or strengthening of structures aims to adapt the existing structure to a new condition, in which minimum security requirements are ensured. Among the techniques currently available (FRANKE; FRANKE; HARTE, 2015), the application of fibre reinforced polymers (FRP) has proved suitable not only for strengthening of contemporary structures but also for the rehabilitation of historical structures (NEGRÃO; BALSEIRO; FARIA, 2011; SCHOBER et al., 2015). This strengthening system, offers advantages such as speed of execution, low self-weight and discreet surface finishing with minimal esthetical interference in some cases.

FRP is a system composed by fibres, impregnated with polymeric matrix, which can be classified, according to the source, in natural and in synthetically made fibres. As example on the FRP building application, sisal can be mentioned as a natural fibre (CARVALHO, 2005) and glass (GFRP), carbon (CFRP), aramid and basalt (THÓRHALLSSON; SNAEBJÖRNSSON, 2017) as synthetic fibres. The fibres can be found in the form of strips and sheets. Strips are unidirectional fibres in an epoxy matrix, while sheets are made of unidirectional or bidirectional fibres, which can be either pre-impregnated or in situ impregnated with resin. They are highly conformable to the surface onto which they are bonded (BAKIS et al., 2002). The mechanical behaviour of the fibres can be predominantly influenced by the temperature (WANG; WONG; KODUR, 2003; CAO; WANG; WU, 2011) and by the loading rate (MAHIEUX; REIFSNIDER, 2002; ELANCHEZHIAN; RAMNATH; HEMALATHA, 2014). The commonly used polymeric matrices in a fibrereinforced composite are epoxy, polyester and acrylate blends (VINSON; SIERAKOWSKI, 1993; KODUR; HARMATHY, 2016). Typically, the matrix has a lower density, stiffness and strength than the fibres (VINSON; SIERAKOWSKI, 1993). The response characteristics for polymeric matrix materials are usually viscoeslastic or viscoplastic and, therefore, they are affected by age, temperature and moisture content (VINSON; SIERAKOWSKI, 1993; GIBSON; ASHBY, 1997; KODUR; HARMATHY, 2016).

Reinforcements with epoxy and FRP, with glass, carbon and basalt fibres, in their different forms, have been applied with the aim of increasing performance and improving the strength and stiffness of structural elements (FIORELLI; DIAS, 2003; BALSEIRO, 2007; NEUBAUEROVÁ, 2012; ROSA; ESCAMILLA; GARCÍA, 2013; BERTOLINI et al., 2014; IANASI, 2015). According to Balseiro (2007), the timber reinforcement with glued fibre laminates has, as the most common failure mode, the delamination, either in the bond line or in the adjacent area. Therefore, research was developed aimed at evaluating the adhesion of the interface reinforcement-wood by shear tests and pull-off of the interface (BALSEIRO, 2007; BARBOSA, 2008; CUSTÓDIO et al., 2009; SERRA, 2010; JUVANDES; BARBOSA, 2012; RUBINI; MORAES, 2012). The shear tests were performed with different bonding lengths, subjected to adverse environmental conditions, such as different wood moisture content and temperature. At temperatures close to the environment, this research has shown that: the average shear strength at the reinforcement-wood interface decreases with increasing bonding length (BALSEIRO, 2007; BARBOSA, 2008; SERRA, 2010; JUVANDES; BARBOSA, 2012); tests in specimens bonded with high moisture content have resulted in very low or zero shear strength values and in failures due to warping and delamination after drying (BALSEIRO, 2007).

In tropical and in some temperate regions, environmental temperatures can easily reach values higher than $30{ }^{\circ} \mathrm{C}$ and high relative air humidity, affecting the structural performance of reinforcements in wooden structures. Several authors have developed research on this topic (CUSTÓDIO; BROUGHTON; CRUZ, 2009; CUSTÓDIO et al., 2009; VALLUZZI et al., 2013, 2016). At high and adverse temperatures, the results were not conclusive on the influence of bonding length on the shear strength (SERRA, 2010). However, for a bonding length of $3 \mathrm{~cm}$, Rubini and Moraes (2012) showed that the average shear strength decreases, in a non-linear way, with the increase in temperature. The pull-off tests showed that the mean tensile strength of the CFRP reinforcements is less than the mean strength directly on the wood surface (JUVANDES; BARBOSA, 2012), but nothing was found on the influence of temperature on these mechanical properties, requiring further research.

This research aims to experimentally evaluate the effect of temperatures between 20 and $80^{\circ} \mathrm{C}$ in the reinforcement adhesion to the wood substrate of Pinus spp. by shear strength tests in specimens reinforced with carbon fibre fabrics and pull-off 
tests in glass fibre reinforced specimens, in order to measure the adequacy of surface preparation before applying a repair or an overlay material.

\section{Materials and methods}

Materials and methods used to carry out shear and pull-off tests, preparation of the specimens, the standards followed, the required equipment for full implementation of the experimental study and the methodology for calculating the strength and the reducing strength factor are presented below.

\section{Materials}

Mechanical tests were carried out using specimens made of timber Pinus spp., with average mass density of $554 \mathrm{~kg} / \mathrm{m}^{3}$ and moisture content of $12.0 \%$, for shear tests, and $13.9 \%$, for pull-off, at room temperature. The timber comes from planted forests in the state of Santa Catarina, Brazil.

Carbon and unidirectional glass fibre fabrics were used. Epoxy-based resins were used as adhesive for attaching the fibres to the wood. For the carbon fibre reinforcement, an epoxy resin, named here as A, was used. This consisted of two components: the base and hardener, which were mixed at a ratio of $3: 1$, as specified by the manufacturer (MCBAUCHEMIE, 2016). For fixing the glass fibre, the two-component epoxy resin (named here as B) was applied. The resin and hardener were mixed in a ratio of $7: 3$, as specified by the manufacturer
(ANCHORTEC, 2017). Mechanical and dimensional properties of the carbon fibre and the resins are shown in Table 1.

\section{Samples and specimens}

The specimens were obtained from visually graded timber, according to the Brazilian standard NBR 7190 (ABNT, 1997), annex G. They were free of defects and were taken from regions far from the piece ends, at least five times the smallest crosssection dimension of the considered timber, but never with less than $30 \mathrm{~cm}$. The timber used for the manufacture of the specimens had dimensions of $2.50 \mathrm{~m}$ in length and cross section of $10.0 \mathrm{~cm} \times 5.0$ $\mathrm{cm}$, approximately.

\section{Shear test}

The timber sample used in the shear test by tension loading was classified into 2 groups with statistically homogeneous mass densities (MONTGOMERY; 2003; MONTGOMERY; RUNGER, 2003), in order to reduce or eliminate the variability transmitted from nuisance factors (MONTGOMERY, 2003). They were named according to the bonding length of the reinforcement. A total of 80 specimens were tested, 40 for each group, 10 for each temperature level (Table 2). Four test sets were carried out, one for each temperature level: 20, 40, 60 and $80{ }^{\circ} \mathrm{C}$, covering the temperature ranges that could naturally occur in a tropical country.

Table 1 - Mechanical and dimensional properties of the fibres and adhesives

\begin{tabular}{|c|c|c|c|c|c|c|}
\hline Components & $\begin{array}{l}\text { Thickness } \\
\text { (mm) }\end{array}$ & $\begin{array}{c}\text { Mass } \\
\text { density } \\
\left(\mathrm{kg} / \mathrm{m}^{3}\right)\end{array}$ & $\begin{array}{c}\text { Tensile } \\
\text { strength } \\
\text { (MPa) }\end{array}$ & $\begin{array}{c}\text { Modulus of } \\
\text { elasticity } \\
\text { (GPa) }\end{array}$ & $\begin{array}{c}\text { Specified } \\
\text { temperature range }\end{array}$ & $\begin{array}{c}\text { Elongation } \\
\text { at rupture } \\
(\%)\end{array}$ \\
\hline Carbon fibre fabric & 0.13 & 1760 & 4,300 & 238.0 & - & 1.8 \\
\hline Fibreglass fabric & 0.27 & 2550 & 85 & 72.4 & Until $800^{\circ} \mathrm{C}$ & 4.8 \\
\hline Adhesive A & - & 1120 & 14 & 3.0 & Between 8 and $40^{\circ} \mathrm{C}$ & - \\
\hline Adhesive B & - & 1050 & 60 & - & $\begin{array}{l}\text { Between -35 and } 80 \\
{ }^{\circ} \mathrm{C} \text { under dry } \\
\text { conditions. } \\
\text { up to } 40^{\circ} \mathrm{C} \text { under } \\
\text { wet conditions }\end{array}$ & 29.0 \\
\hline
\end{tabular}

Source: Mc-Bauchemie (2016) and Anchortec (2017).

Table 2 - Number of shear specimens for each temperature level

\begin{tabular}{c|c|c|c|c|c|c}
\hline \multirow{2}{*}{ Groups } & Mass density & \multicolumn{4}{|c|}{ Number of specimens for testing } & \multirow{2}{*}{ Total } \\
\cline { 3 - 6 } & $\left(\mathbf{k g} / \mathbf{m}^{3}\right)$ & $\mathbf{2 0}^{\circ} \mathbf{C}$ & $\mathbf{4 0}^{\circ} \mathbf{C}$ & $\mathbf{6 0}^{\circ} \mathbf{C}$ & $\mathbf{8 0}^{\circ} \mathbf{C}$ & \\
\hline PRFC 4 cm & 457 a 644 & 10 & 10 & 10 & 10 & 40 \\
PRFC 5 cm & 463 a 643 & 10 & 10 & 10 & 10 & 40 \\
\hline & & & & & Total & 80 \\
\hline
\end{tabular}


The specimen used in the determination of the shear strength of the reinforcement is shown in Figure 1. The specimen shape was determined from the results of Balseiro (2007), after preliminary studies, so that there was no failure by crushing in the fixing rod region and also no force eccentricity with relation to the reinforcement shear line. The bonding lengths are $4.00 \mathrm{~cm}$ and $5.00 \mathrm{~cm}$ CFRP. A spacing of $0.50 \mathrm{~cm}$ was left between the two segments of the specimen to avoid leverage between the parts, should any eccentricity in the resulting applied load occur.

Figure 1 - Specimen with reinforcement

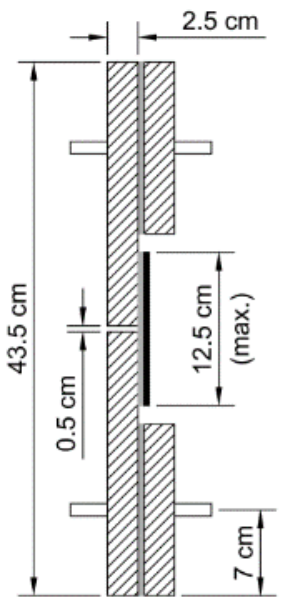

(a) Left side

\section{Preparation of the specimens}

The manufacture of the shear test specimens was performed in four steps, according to the supplier technical specifications (MC-BAUCHEMIE, 2016): scarifying the surface; applying the adhesive A on the rough surface; adhesive application on the carbon fibre, passing the roller and curing of the specimen (Figure 2). The bonding surfaces of the specimens receiving reinforcement were treated with chisel to increase its initial roughness (Figure 2a). Thus, grooves were made in different directions in relation to the wood fibres.

Figure 2 - Manufacturing process of the specimen

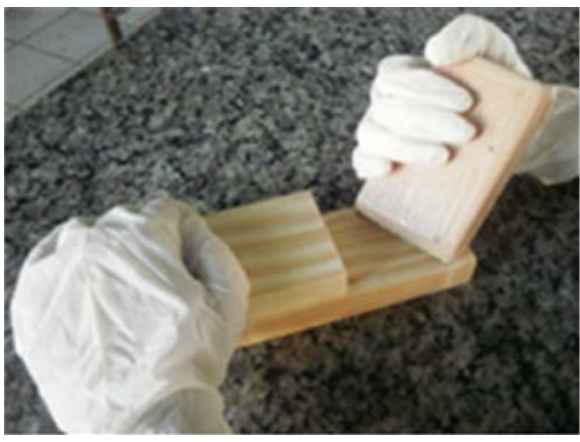

(a) Surface scarification

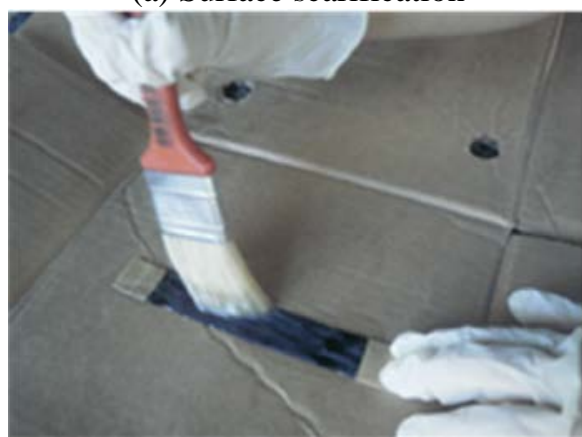

(c) Adhesive application in carbon fibre

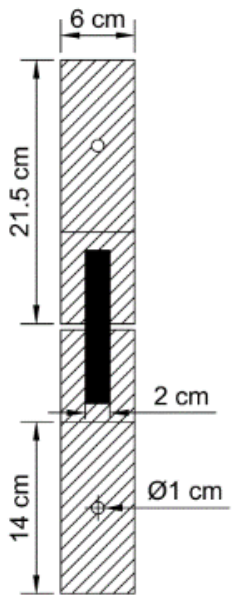

LEGEND

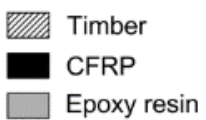

(b) Front

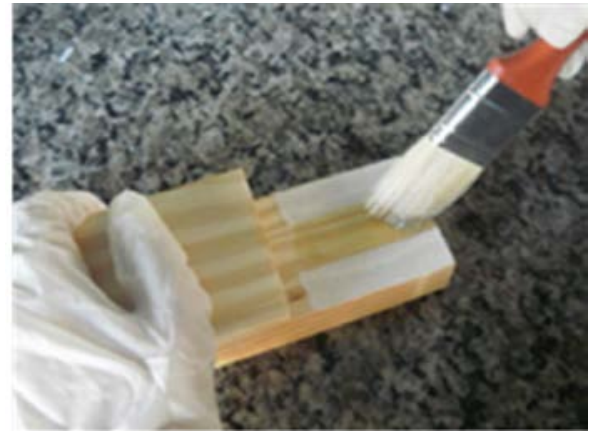

(b) Adhesive application on the rough surface

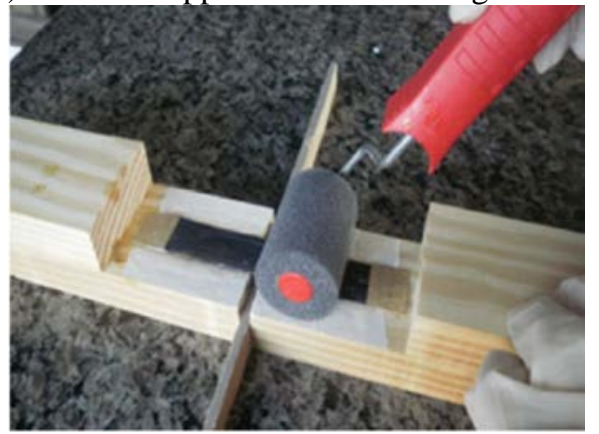

(d) Application of the impregnation roll 
The adhesive was applied with a brush, always being careful not to let air bubbles and to obtain an approximately uniform thick layer (Figure 2b, 2c). Once applied to the carbon fibre, a roller was used to remove all possible air bubbles (Figure 2d). In order to ensure uniformity of the bond line, the technical staff who prepared the specimens was trained to perform this activity. A period of seven days was observed from the beginning of the gluing until the realization of the mechanical test, to complete the curing process.

\section{Mechanical testing apparatus}

The mechanical tests were performed in a thermal chamber coupled to a universal testing machine with a load cell of $50 \mathrm{kN}$, with an accuracy of 0.005 $\mathrm{kN}$. The thermal chamber allowed the ambient air conditioning to reach the temperature levels of 20 , 40, 60 and $80^{\circ} \mathrm{C}$, as specified in sequence.

\section{Pull-off tests}

Glass fibre pull-off of the timber was performed as specified by ASTM C 1583 (AMERICAN..., 2013), prescribing the pull-off through the bonding of a metal disc with a central hole, in which, by means of a screw, the pull-out force of the disc specimen is applied. In this research, the metal disc had a diameter of $50 \mathrm{~mm}$ and thickness of $10 \mathrm{~mm}$, resulting in a contact surface of $1963.5 \mathrm{~mm}^{2}$.

Tests were performed at three temperature levels: ambient $\left(28{ }^{\circ} \mathrm{C}\right), 60$ and $80{ }^{\circ} \mathrm{C}$, covering the temperature range that could naturally occur in a tropical country. The ambient temperature was 28
${ }^{\circ} \mathrm{C}$, since the laboratory thermal chamber had no cooling facility.

For the pull-off tests, six specimens were prepared with dimensions of $30 \mathrm{~cm} \times 10 \mathrm{~cm} \times 5 \mathrm{~cm}$ (Figure $3)$. This geometric configuration was defined from preliminary studies, allowing four pull-off data on each specimen. In total, 24 data sets were obtained from 6 specimens, with 8 pull-out tests by temperature level (Table 3).

\section{Manufacture of the specimens}

The manufacture of the specimens for the pull-off test was performed in four steps by trained technical staff. According to ASTM C 1583 (AMERICAN..., 2013), the glass fibre fabric was cut into strips of dimensions $30 \mathrm{~cm} \times 10 \mathrm{~cm}$. In previous research, adhesion issues were verified caused by smooth surface or by chemical inactivation of wood surface by external or self-contamination (CUSTÓDIO et al., 2009). Therefore, in order to increase the surface roughness, the timber was treated with sandpaper grain grit class 40 according to ANSI B74.12 (AMERICAN..., 2012) and cleaned with a cloth. For fibre fixing, an adhesive B layer was applied uniformly to the largest faces of the specimens (Figure 4a) and to the glass fibre reinforcement (Figure 4b). Subsequently, the fibre was pressed on the specimen (Figure 4c) and another adhesive layer was applied to ensure complete adhesion between the fibre and the timber (Figure 4d), according the manufacturing specifications (ANCHORTEC, 2017). The specimens were tested after an adhesive curing period of 7 days.

Figure 3 - Specimen dimensions and position of the pull-off tests

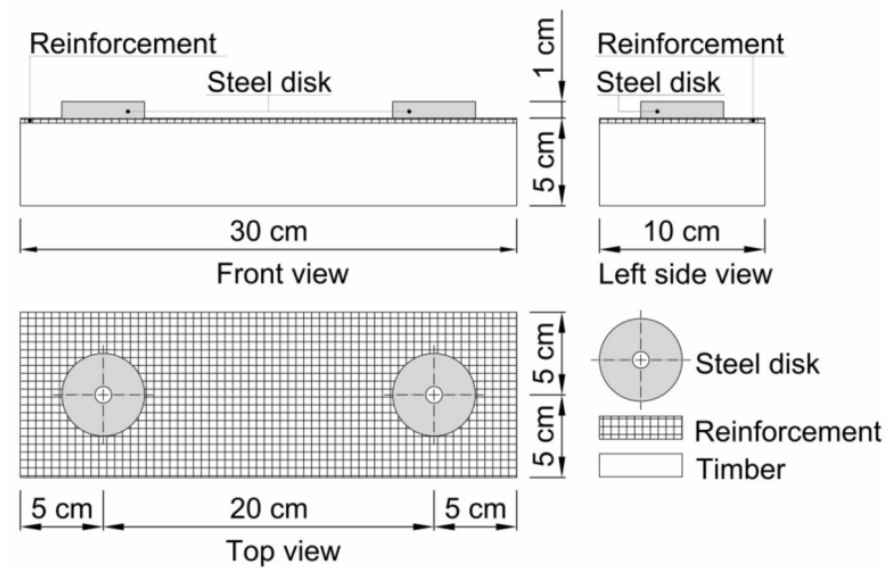

Table 3 - Number of pull-off tests for temperature levels

\begin{tabular}{c|c|c|c|c}
\hline Specimens & \multicolumn{3}{|c|}{ Number of pull-off } & Total \\
\hline & $28{ }^{\circ} \mathrm{C}$ & $60^{\circ} \mathrm{C}$ & $80^{\circ} \mathrm{C}$ & \\
6 & 8 & 8 & 8 & 24 \\
\hline
\end{tabular}


Figure 4 - Procedure for applying the glass fibre on timber surface: (a) first layer of epoxy resin on timber surface; (b) second resin layer on the glass fibre; (c) placement of fibreglass on the surface; e (d) third resin layer on the fibre already positioned
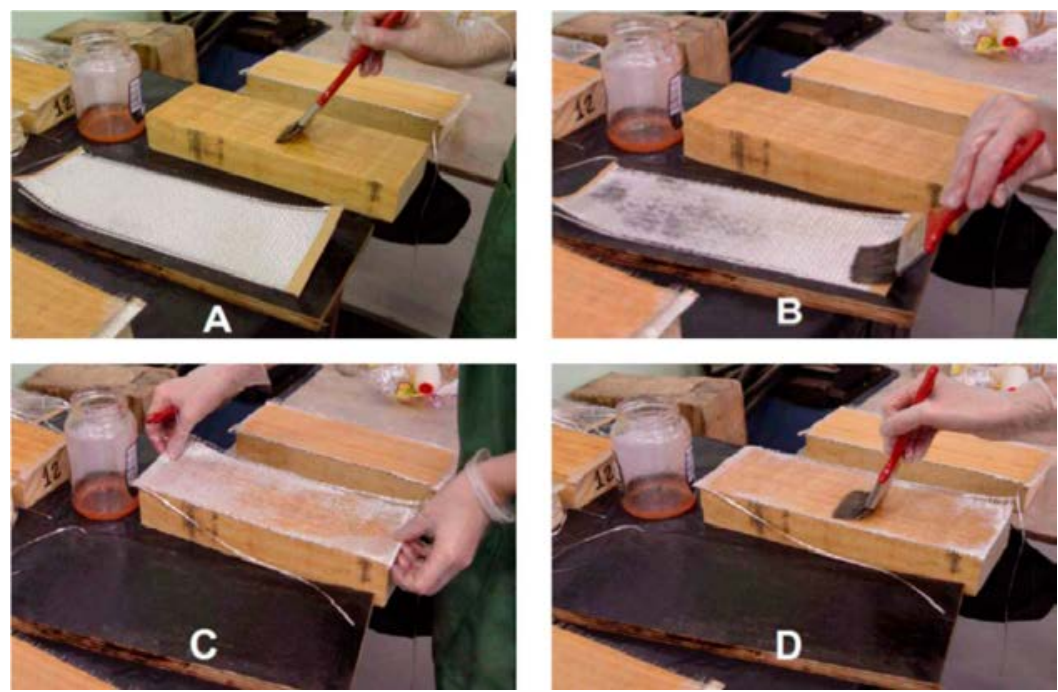

After the bonding of the fibres and the adhesive cure, the specimens were cut with a hole saw in order to delimit the pull-off area, as specified by ASTM C 1583 (AMERICAN..., 2013). The adhesive $\mathrm{A}$, used for fixing the metal discs on the surface of the fibre reinforced specimens, was chosen after preliminary studies.

\section{Pull-off procedures}

The equipment used to perform the pull-off tests was a digital dynamometer, with an accuracy of $0.01 \mathrm{kN}$ and a maximum capacity load of $20 \mathrm{kN}$. It had a memory device that records the maximum tensile strength during the test.

The test began with the application of an initial force of about $0.50 \mathrm{kN}$, measured on the dynamometer equipment. A tensile load was applied as the handle was rotated at a constant speed, until failure occurred. The failure load and mode were recorded and the nominal tensile stress at failure was calculated.

\section{Heating of the specimens}

The heating time of the specimens in the two tests was determined by preliminary studies, to ensure the desired adhesive temperature, according to Serra (2010). The shear specimens in tension loading were preheated for $120 \mathrm{~min}$. After that, the specimens were transferred to the heated thermal chamber attached to the testing machine.

The pull-off specimens were heated for different periods of time: $120 \mathrm{~min}$ for the tests at $60^{\circ} \mathrm{C}$ and $140 \mathrm{~min}$ for the tests at $80^{\circ} \mathrm{C}$. After heating, the dynamometer and the specimen were transferred to

the thermal chamber heated at the test temperature and the tests were performed keeping open the chamber door.

\section{Determination of wood moisture content}

The determination of moisture content (MC) of shear test specimens was carried out using the specimens themselves. They were dried up in an electric oven. According to NBR 7190 (ASSOCIAÇÃO..., 1997), wood moisture content is calculated as the ratio of the mass of water and the dry mass of the wood, given by Equation 1:

$\operatorname{MC}(\%)=\frac{m_{\mathrm{f}}-\mathrm{m}_{\mathrm{d}}}{\mathrm{m}_{\mathrm{d}}} \times 100$

Eq. 1

In which:

$m_{f}$ is the final mass of the specimen at the end of the shear test, in g; and

$m_{d}$ is the dry mass of the specimen, in g.

The specimens were weighted at the end of the tests to determine the final mass $\left(m_{f}\right)$. After that, they were dried up in an oven at a temperature of $103 \pm$ $2{ }^{\circ} \mathrm{C}$ until a weight change between two consecutive measurements of less than or equal to $0.5 \%$ is detected. The last mass measurement was considered the dry mass $\left(m_{d}\right)$.

In order to determine the moisture content of the pull-off test specimens, a hygrometer was used. The equipment had calibration for four wooden mass densities groups, accuracy of measurement of $0.1 \%$ and calibration for offsetting temperature from 0 to $80^{\circ} \mathrm{C}$. 


\section{Determination of shear strength}

Shear strength at a temperature level $\theta\left(f_{v, \theta}\right)$ was determined by the ratio of the maximum tensile force acting on the specimen at a given temperature and the shear area, according to Equation 2.

$f_{\mathrm{V}, \theta}=\frac{\mathrm{Fv}, \mathrm{max}}{\mathrm{A}_{\mathrm{v}}}$

In which:

Fv,max is the maximum force applied at the end of the specimen, in $\mathrm{N}$, at a given temperature $\theta$, and

$A_{v}$ is the rupture projected area of the specimens, in $\mathrm{mm}^{2}$, adapted from EN 14374 (EUROPEAN..., 2004).

The criterion to consider the shear tests as valid was that the rupture projected area should not exceed $20 \%$ of the contact area between the reinforcement and the specimen EN 14374 (EUROPEAN..., 2004). When the rupture occurs in the substrate, the failure surface can be bigger than the reinforcement shear area on the substrate or it is a curved surface. In these cases, the failure area was defined by the projection of the rupture surface on the adhesive shear plane.

\section{Determination of the pull-off strength}

The bond or tensile strength $\left(f_{p o, \theta}\right)$ value at temperature $\theta$ is defined by Equation 3 .

$f_{\mathrm{V}, \theta}=\frac{\mathrm{Fv}, \mathrm{max}}{\mathrm{A}_{\mathrm{v}}}$

In which:

$F_{p o, \max }$ is the maximum tension load registered by the dynamometer, in $\mathrm{N}$, at a given temperature $\theta$; and

$A_{p o}$ is the contact area between the test specimen and the metal disc, in $\mathrm{mm}^{2}$.

The Standard ASTM C 1583 (AMERICAN..., 2013) gives as non-valid the tests in which the failure occurs at the bond line between the steel disc and the epoxy adhesive in the substrate. But, in this paper, this criterion was not considered. All results were included in the statistical analysis independently of the rupture type.

\section{Determination of strength reduction factor}

The reduction factor at a temperature level $\theta\left(k_{\theta}\right)$ is calculated by Equation 4.

$$
k_{\theta}=\frac{\overline{f_{\theta}}}{\overline{f_{a m b}}}
$$

Iin which:

$\overline{f_{\theta}}$ is the average strength in $\mathrm{N} / \mathrm{mm}^{2}$ at a given temperature $\theta$, and

$\overline{f_{a m b}}$ is the average strength in $\mathrm{N} / \mathrm{mm}^{2}$, at room temperature.

\section{Statistical analysis}

The statistical analysis was applied to assess the influence of the temperature on the shear and pulloff strength and the reinforcement lengths on the shear tests results. For the analysis of results, the existence of outlier values was initially verified (NATIONAL..., 2013). In shear strength results, two analyses were carried out separately: one to verify the influence of the temperature and other to verify the influence of the reinforcement lengths. The nonparametric Kruskal-Wallis test was applied at the 95.0\% confidence level (MONTGOMERY, 2003; MONTGOMERY; RUNGER, 2003), since the assumption of independence, normality and homogeneity of data variance was not verified. More details about the statistical analysis can be found in Montgomery (2003) and Montgomery and Runger (2003).

\section{Results and discussion}

In this section, the results of the experimental investigation, moisture content, types of rupture, shear and pull-off strength in the reinforced elements are presented and discussed.

\section{Wood moisture content}

Moisture content of the specimens of shear and pulloff tests are presented in Figure 5. At room temperature, the average moisture content was $12.0 \%$ and $13.9 \%$, for shear and pull-off tests, respectively. As expected, the reduction of moisture content with increasing temperature was observed. The bound water in the cell wall probably was not completely released due to the experimental heating process, since the highest temperature in the tests was $80^{\circ} \mathrm{C}$. According to Young and Clancy (2001), bound water evaporation begins at $100^{\circ} \mathrm{C}$.

\section{Shear strength of the glued interface}

The test results of carbon fibre timber specimens and adhesive A are presented in Figure 6 together with the average results obtained by Serra (2010) and by Rubini and Moraes (2012), both for Pinus spp. At room temperature, the average shear strength of the $4 \mathrm{~cm}$ reinforcement was $8.1 \mathrm{MPa}$, while for the $5 \mathrm{~cm}$ reinforcement was $5.7 \mathrm{MPa}$. The 
average shear strength obtained for the $5 \mathrm{~cm}$ reinforcement was lower than the value of $6.7 \mathrm{MPa}$ obtained by Serra (2010) for $5 \mathrm{~cm}$ length, at room temperature.

At $40{ }^{\circ} \mathrm{C}$, the shear strength of $4 \mathrm{~cm}$ CFRP is higher than that at the room temperature. However, at 60 and $80^{\circ} \mathrm{C}$, the shear strength value is lower than that at room temperature. These results confirm the range of 8 to $40^{\circ} \mathrm{C}$ for the temperature application, specified by the product data sheets (MCBAUCHEMIE, 2016). It should be stressed that the number of the $4 \mathrm{~cm}$ reinforcement test repetitions was reduced, due to manufacture defects, from 10 to 8 and 10 to 6 at 40 and $60{ }^{\circ} \mathrm{C}$, respectively.
Concerning the temperature, the non-parametric Kruskal-Wallis test (MONTGOMERY, 2003; MONTGOMERY; RUNGER, 2003) indicates that there is statistical difference between the shear strength at 20 and those at $80{ }^{\circ} \mathrm{C}$, as presented by Table 4 . This behaviour could be explained by the test temperature approaching that of adhesive glass transition (Tg) of $94.9^{\circ} \mathrm{C}$ (Silva, M.M.V. Personal communication, September 3, 2016). The mechanical properties of the polymer matrix are highly temperature dependent: as temperature increases, the material behaviour changes from a hard glassy state to a soft rubbery state, according to Mahieux and Reisfsnider (2002).

Figure 5 - Moisture content of the specimens

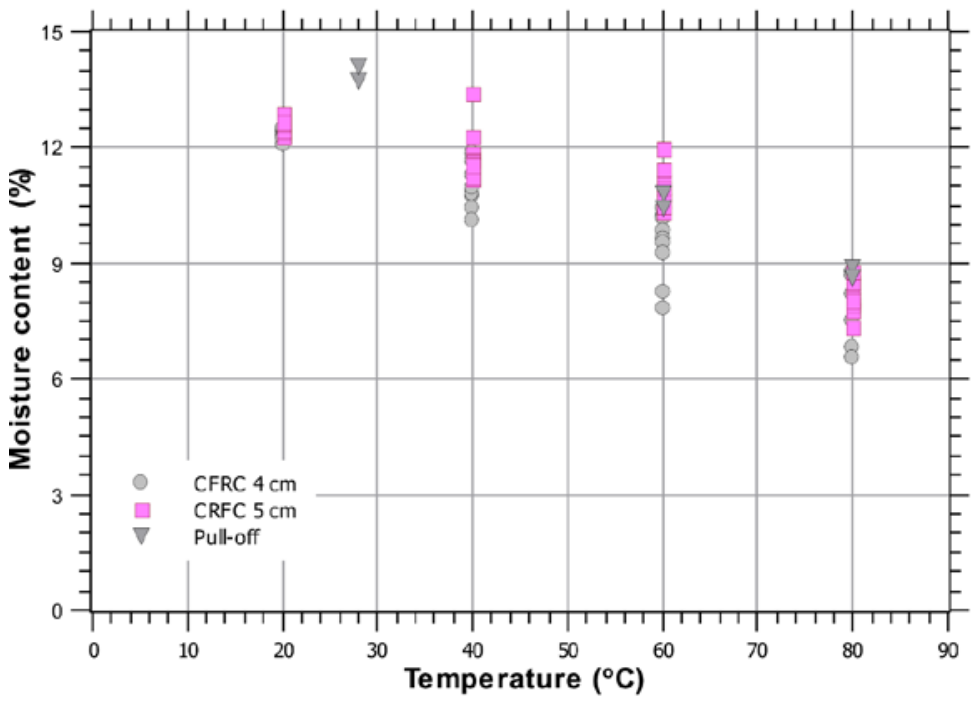

Figure 6 - Shear reinforcement strength

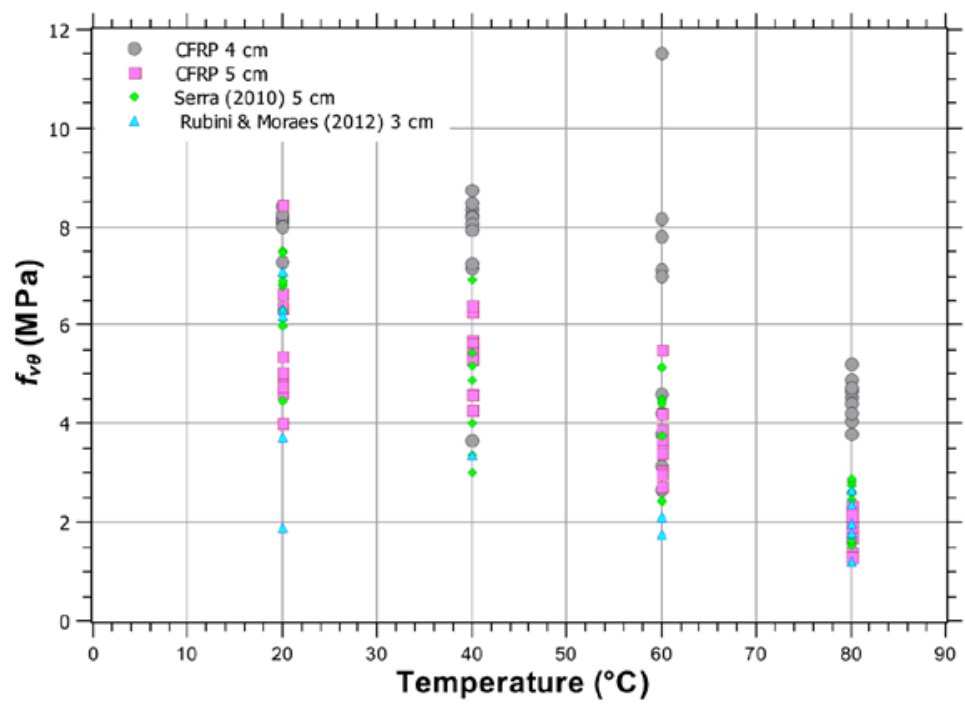


Table 4 - Statistical analysis results of shear strength for each reinforcement length

\begin{tabular}{c|c|c}
\hline Reinforcement length (cm) & Temperature $\left({ }^{\circ} \mathbf{C}\right)$ & $f_{\boldsymbol{v}, \boldsymbol{\theta}} \mathbf{( M P a )}$ \\
\hline \multirow{3}{*}{4.0} & 20 & $8.1(0.3) \mathrm{a}$ \\
& 40 & $8.1(3.0) \mathrm{a}$ \\
& 60 & $7.6(4.2) \mathrm{ab}$ \\
& 80 & $4.5(0.4) \mathrm{b}$ \\
\hline \multirow{2}{*}{5.0} & 20 & $5.7(1,3) \mathrm{a}$ \\
& 40 & $5.1(1.1) \mathrm{ac}$ \\
& 60 & $3.3(0.5) \mathrm{bc}$ \\
& 80 & $1.9(0.4) \mathrm{b}$ \\
\hline
\end{tabular}

Note: values between parenthesis corresponding to standard deviation; mean values in the same column followed by the same letter are not statistically different at $95.0 \%$ confidence level according to Kruskal-Wallis test (MONTGOMERY, 2003; MONTGOMERY; RUNGER, 2003).

Statistical analysis results of shear strength, for each temperature level, are presented in Table 5. For all temperature levels, the test shows statistical difference between the shear strength of the 4 and 5 $\mathrm{cm}$ reinforcement, corroborating the results obtained by Balseiro (2007), Barbosa (2008) and Juvandes and Barbosa (2012), at room temperature. Their results show that the shear strength decreases with increasing adhesion length. However, the results of Serra (2010), due to the reduced number of repetitions, were not conclusive on this topic. Future studies should be developed, in a unified experimental project, with a larger number of different bonding lengths in order to clarify the temperature influence.

\section{Pull-off strength}

Figure 7 illustrates the pull-off strength obtained in fibreglass timber specimens with adhesive $\mathrm{B}$. The types of rupture of pull-off specimens are presented in Table 6. At room temperature, the failure occurred completely or partially in the substrate in 7 out of 8 tests. At 60 and $80^{\circ} \mathrm{C}$, all failures occurred at the epoxy interface between the glass fibre and the metal discs, where Adhesive A was applied. All results are included in the statistical analysis. The failure types suggest that bond line delamination between the disc and the glass fibre was due to the smooth surface of the metal.

The Standard NBR 7190 (ASSOCIAÇÃO..., 1997) criterion concerning moisture was applied and the pull-off strength of $2.4 \mathrm{MPa}$ at room temperature was adjusted to $12 \%$ moisture content. At $60^{\circ} \mathrm{C}$, the pull-off strength was $1.6 \mathrm{MPa}$ and $0.5 \mathrm{MPa}$ at $80^{\circ} \mathrm{C}$. The room temperature results are similar to those found in the literature. Previous studies by Nardon (2010) found pull-off strength of Picea spp. specimens, with wood mass density of $405 \mathrm{~kg} / \mathrm{m}^{3}$ and $10 \%$ moisture content, as approximately 2.1 $\mathrm{MPa}$ at room temperature. Juvandes and Barbosa
(2012) found the mean value of pull-off strength of Picea abies and carbon fibre specimens as $2.41 \pm$ $0.65 \mathrm{MPa}$, at room temperature, with timber classified as Class C30 (EUROPEAN..., 2016), that is equivalent to the mean density of $460 \mathrm{~kg} / \mathrm{m}^{3}$.

For all temperature levels, the non-parametric Kruskal-Wallis test results show statistical differences between the pull-off strength at $28{ }^{\circ} \mathrm{C}$ and at the other temperatures, presented in Table 7.

\section{Temperature strength reduction factor}

Figure 8 illustrates the average reduction factors of shear and pull-off experimental strengths, with shear reinforcement lengths of 4 and $5 \mathrm{~cm}$ at room temperature, at 60 and at $80{ }^{\circ} \mathrm{C}$. The shear strength reduction factor is in the range from 0.95 to 0.59 , at $60{ }^{\circ} \mathrm{C}$, and from 0.56 to 0.34 , at $80{ }^{\circ} \mathrm{C}$, while reduction factors of pull-off strength are 0.67 and 0.20 , at 60 and $80{ }^{\circ} \mathrm{C}$, respectively.

The temperature influence on the shear and pull-off strengths shows similarities at various temperature levels (Figure 8) except in CFRC $4 \mathrm{~cm}$. In general, the mean strengths decrease as the temperature increases as a nonlinear function. This decrease is expected, mainly because of the epoxy resin thermal changes and the vicinity of matrix glass transition temperature (Tg) (MAHIEUX; REIFSNIDER, 2002). According to the manufacturers, the adhesives used in this work are recommended to be applied at temperatures below $40^{\circ} \mathrm{C}$, in case of carbon fibre applications, or below $80^{\circ} \mathrm{C}$ for glass fibre reinforcement (Table 1). At 40 ${ }^{\circ} \mathrm{C}$, the strength reduction factors were below 1.0, except in the CRFP reinforcement at bonding lengths of $4 \mathrm{~cm}$ (Figure 8), even though the temperature was within the temperature range specified by the manufacturers. This may affect the reinforcement safety. Caution in using such resins is required at high temperatures. 
Table 5 - Statistical analysis results of shear strength for each temperature level

\begin{tabular}{c|c|c}
\hline Temperature $\left({ }^{\circ} \mathbf{C}\right)$ & Reinforcement length $(\mathbf{c m})$ & $f_{v}, \boldsymbol{\theta}(\mathbf{M P a})$ \\
\hline \multirow{2}{*}{20} & 4.0 & $8.1(0.3) \mathrm{b}$ \\
\cline { 2 - 3 } & 5.0 & $5.7(1,3) \mathrm{a}$ \\
\hline \multirow{2}{*}{40} & 4.0 & $8.1(4.2) \mathrm{b}$ \\
\cline { 2 - 3 } & 5.0 & $5.1(1.1) \mathrm{a}$ \\
\cline { 2 - 3 } & 4.0 & $7.6(4.2) \mathrm{b}$ \\
\hline \multirow{2}{*}{60} & 5.0 & $3.3(0.5) \mathrm{a}$ \\
\cline { 2 - 3 } & 4.0 & $1.5(0.4) \mathrm{b}$ \\
\hline \multirow{2}{*}{80} & 5.0 & $0.4) \mathrm{a}$ \\
\hline
\end{tabular}

Note: values between parenthesis corresponding to standard deviation; mean values in the same column followed by the same letter are not statistically different at $95.0 \%$ confidence level according to Kruskal-Wallis test (MONTGOMERY, 2003; MONTGOMERY; RUNGER, 2003).

Figure 7 - Pull-off strength of fibreglass reinforcement

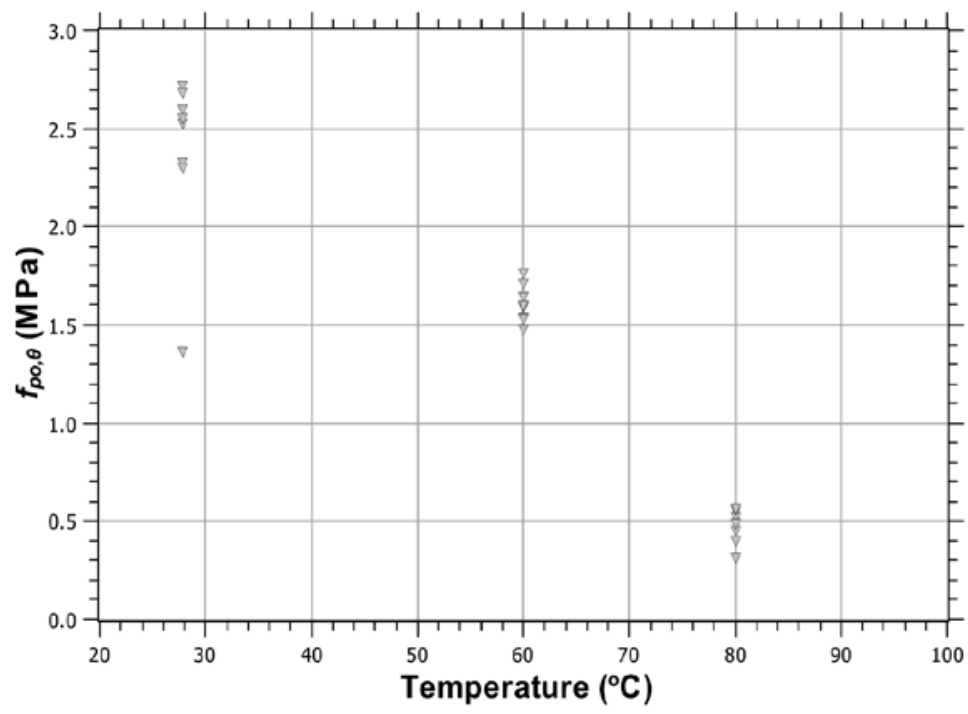

Table 6 - Types of rupture in pull-off tests for each temperature level

\begin{tabular}{c|l|c}
\hline \multirow{2}{*}{ Temperature } & \multicolumn{1}{c|}{ Type of rupture } & $\begin{array}{c}\text { Number of } \\
\text { specimens }\end{array}$ \\
\hline \multirow{3}{*}{$28^{\circ} \mathrm{C}$} & $100 \%$ of surface rupture in substrate & 6 \\
\cline { 2 - 3 } & $\begin{array}{l}70 \% \text { of surface rupture in substrate and 30\% in glue line between the } \\
\text { substrate and the fibre }\end{array}$ & 1 \\
\cline { 2 - 3 } & $100 \%$ of surface rupture in glue line between the disk and the fibreglass & 1 \\
\hline $60^{\circ} \mathrm{C}$ & $100 \%$ of surface rupture in glue line between the disk and the fibreglass & 6 \\
\hline $80^{\circ} \mathrm{C}$ & $100 \%$ of surface rupture in glue line between the disk and the fibreglass & 6 \\
\hline
\end{tabular}

Table 7 - Statistical analysis results of pull-off strength for temperature levels

\begin{tabular}{c|c}
\hline $\begin{array}{c}\text { Temperature } \\
\left({ }^{\circ} \mathbf{C}\right)\end{array}$ & $\begin{array}{c}\boldsymbol{f}_{\text {po }, \boldsymbol{\theta}} \\
(\mathbf{M P a})\end{array}$ \\
\hline 20 & $2.4(0.4) \mathrm{a}$ \\
60 & $1.6(0.1) \mathrm{a}$ \\
80 & $0.5(0.1) \mathrm{b}$ \\
\hline
\end{tabular}

Note: values between parenthesis corresponding to standard deviation; mean values in the same column followed by the same letter are not statistically different at $95.0 \%$ confidence level according to Kruskal-Wallis test (MONTGOMERY, 2003; MONTGOMERY; RUNGER, 2003). 
Figure 8 - Reduction factors of shear and pull-off strengths

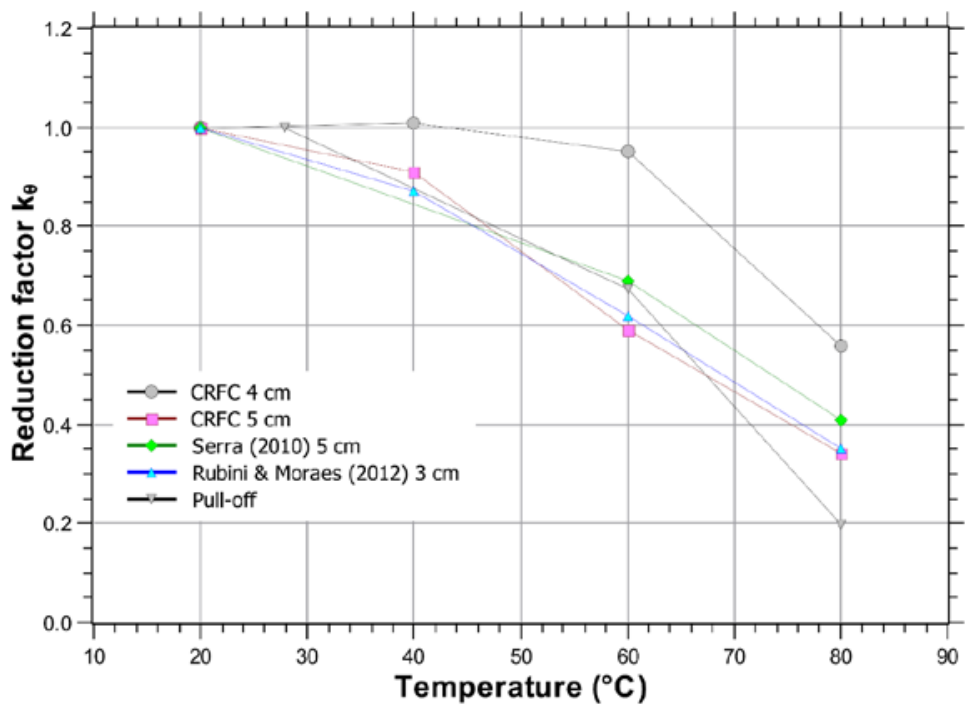

From the results in Tables 4 and 7, the adhesion strength reduction of the resin line at room temperature is recommended when the ambient temperature may reach $60{ }^{\circ} \mathrm{C}$ or higher. The recommended reduction factors, for these particular conditions, are 0.59 and 0.20 for predicted maximum temperature of 60 and $80{ }^{\circ} \mathrm{C}$, respectively. The wood surface preparation is also suggested by scrapping off and cleaning, in order to improve mechanical engagement of the joint. A complementary evaluation for determining the roughness level for application of reinforcement on timber surface is suggested, in order to assess the influence of reinforcement lengths. Additional research is required on this topic.

\section{Conclusions}

In this research, the influence of temperature on the adhesion of polymer reinforcement to wooden substrate was evaluated by pull-off and shear by tension loading, in the range from 20 to $80^{\circ} \mathrm{C}$. The specimens were made with the wood species Pinus spp., with mass density of $554 \mathrm{~kg} / \mathrm{m}^{3}$ and moisture content of $12 \%$, carbon and glass fibres and epoxy adhesives. The results obtained indicate that:

(a) there is statistical difference between the 4 and $5 \mathrm{~cm}$ reinforcement strengths; additional research is required for lengthier reinforcements;

(b) the epoxy adhesive strength is sensitive to temperature increase and presents nonlinear behaviour;

(c) the reinforcement adhesion decreases with the temperature increase and a strength reduction factor is recommended when the ambient temperature reaches $60^{\circ} \mathrm{C}$ or higher, with values of 0.59 and 0.20 for predicted maximum temperature of 60 and $80{ }^{\circ} \mathrm{C}$, respectively; and

(d) caution in using the applied resins is required due to the reported behaviour, even in the service temperature range specified by the manufacturers.

The substrate roughness affects the reinforcement adherence, requiring an adequate preparation of the wood surface in order to improve the mechanical engagement of the joint. Additional research is required to assess its influence.

\section{References}

\section{AMERICAN NATIONAL STANDARDS}

INSTITUTE. B74.12: specification for the size of abrasive grain - grinding wheels, polishing and general industrial uses. Washington, 2012.

\section{AMERICAN SOCIETY FOR TESTING AND}

MATERIALS. C 1583: standard test method for tensile strength of concrete surfaces and the bond strength or tensile strength of concrete repair and overlay materials by direct tension (Pull-off method). Philadelphia, 2013.

ANCHORTEC. Fosfiber C - Nitobond CF55: sistema de reforço estrutural com fibra de carbono. Available from:

$<$ https://www.quartzolit.weber/solucoes-tecnicasquartzolit-para-reparos-protecao-ereforco/reforcos-de-estruturas-fibra-decarbono/weberrep-weberrep-fiber-c-quartzolit>. Access at: 09 dec. 2017. 
ASSOCIAÇÃO BRASILEIRA DE NORMAS TÉCNICAS. NBR 7190: norma de projeto de estruturas de madeira. Rio de Janeiro, 1997.

BAKIS, C. E. et al. Fiber-Reinforced Polymer Composites for Construction: State-of-the-Art review. Journal of Composites for Construction, v. 6, n. 2, p. 73-87. 2002.

BALSEIRO, A. M. R. Reforço e Reabilitação de Vigas de Madeira Por Pré-Esforço Com Laminados FRP. Porto, 2007. 143 f. Dissertação (Mestrado Integrado em Engenharia Civil) Faculdade de Engenharia, Universidade do Porto, Porto, 2007.

BARBOSA, R. M. T. Estruturas de Madeira Lamelada Colada Reforçada Com Sistemas Compósitos de FRP: análise da aderência entre os materiais. Porto, 2008. 168 f. Dissertação (Mestrado Integrado em Engenharia Civil) Faculdade de Engenharia, Universidade do Porto, Porto, 2008.

BERTOLINI, M. S. et al. Emprego de Resina Epóxi em Vigas Danificadas de Madeira de Pinus elliottii. Ambiente Construído, Porto Alegre, v. 14, n. 3, p. 121-129, jul./set. 2014.

CAO, S.; WANG, X.; WU, Z. Evaluation and Prediction of Temperature-Dependent Tensile Strength of Unidirectional Carbon FiberReinforced Polymer Composites. Journal of Reinforced Plastics and Composites, v.30, n. 9, p. 799-807, 2011.

CARVALHO, R. F. Compósitos de Fibras de Sisal Para Uso em Reforço de Estruturas de Madeira. São Carlos, 2005. 133 f. Tese (Doutorado em Ciência e Engenharia de Materiais) - Escola de Engenharia, Universidade de São Paulo, São Carlos, 2005.

CRUZ, H. Patologia, Avaliação e Conservação de Estruturas de Madeira. In: CURSO LIVRE INTERNACIONAL DE PATRIMÓNIO, 2., Santarém, 2001. Anais... Santarém: Forum UNESCO, 2001.

CUSTÓDIO, J. et al. Thermal Stability of Epoxy and Polyurethane Adhesives and Bonded Joints Used in the Rehabilitation of Timber Structures. In: JORNADAS CHILENAS DE ESTRUCTURAS DE MADERA, 3.; CONGRESO LATINO AMERICANO DE ESTRUCTURAS DE MADERA. CONCEPCIÓN, 1., Concepción, 2009. Anais... Chile: Universidad del Bío Bío, Concepción, 2009.
CUSTÓDIO, J.; BROUGHTON, J.; CRUZ, H. A Review of Factors Influencing the Durability of Structural Bonded Timber Joints. International Journal of Adhesion and Adhesives, v. 29, n. 2, p. 173-185, mar. 2009.

ELANCHEZHIAN, C.; RAMNATH, B. V.; HEMALATHA, J. Mechanical Behaviour of Glass and Carbon Fibre Reinforced Composites at Varying Strain Rates and Temperatures. Procedia Materials Science, v. 6, p. 1405-1418, 2014.

EUROPEAN COMMITTEE FOR

STANDARDIZATION. EN 14374: timber structures: structural laminated veneer lumber: requirements. Luxembourg, 2004.

\section{EUROPEAN COMMITTEE FOR}

STANDARDIZATION. EN 338: structural timber: strength classes. Luxembourg, 2016.

FIORELLI, J.; DIAS, A. A. Analysis of the Strength and Stiffness of Timber Beams Reinforced With Carbon Fiber and Glass Fiber. Materials Research, São Carlos, v. 6, n. 2, p. 193202, jun. 2003.

FRANKE, S.; FRANKE, B.; HARTE, A. M. Failure Modes and Reinforcement Techniques for Timber Beams: state of the art. Construction and Building Materials, v. 97, p. 2-13, oct. 2015.

GIBSON, L. J.; ASHBY, M. F. Cellular Solids: structure and properties (Cambridge Solid State Science Series). Cambridge: Cambridge University Press. 1997.

IANASI. A. C. On the Role of CFRP Reinforcement for Wood Beams Stiffness. IOP Conference Series: Materials Science and Engineering, v. 95, 012015, 2015.

JUVANDES, L. F. P.; BARBOSA, R. M. T. Bond Analysis of Timber Structures Strengthened With FRP Systems. Strain, Wiley, v. 48, n. 2, p. 124135, apr. 2012.

KODUR, V. K. R.; HARMATHY, T. Z. Properties of Building Materials. In: HURLEY, M. J. et al. (Eds.). SFPE Handbook of Fire Protection Engineering. New York: Springer, 2016.

MAHIEUX, C. A.; REIFSNIDER, K. L. Property Modeling Across Transition Temperatures in Polymers: application to thermoplastic systems. Journal of Materials Science, v. 37, n. 5, p. 911920, 2002. 
MC-BAUCHEMIE. MC-DUR 1209: resina de laminação para reforço estrutural com manta de fibra de carbono. 2016. Available from: $<$ http://www.mc-bauchemie.com.br/produtos/mcpara-infraestrutura-e-industria/recuperacao-doconcreto/adesivos-epoxidicos/mc-dur-1209/>. Access at: 30 sep. 2016.

MONTGOMERY, C. Design and Analysis of Experiments. $5^{\text {th }}$ ed. Wiley: New York, 2003.

MONTGOMERY, C.; RUNGE, R. C. Applied Statistics and Probability for Engineers. $3^{\text {rd }}$ ed. Wiley: New York, 2003.

NARDON, F. Durabilità di Sistemi di Rinforzo di Elementi in Legno Con Materiali Compositi a Matrice Polimerica. Padova, 2010. 81 f. Tesi (Laurea Specialistica in Scienze e Tecnologie per i Beni Archeologici e Artistici, Facoltà di Ingegneria) - Dipartimento di Costruzioni e Trasporti e Facoltà di Scienze MM. FF. NN. Dipartimento di Scienze Chimiche, Università degli Studi di Padova, Padova, 2010.

NATIONAL INSTITUTE OF STANDARDS AND TECHNOLOGY/SEMATECH. eHandbook of Statistical Methods. NIST/SEMATCEH: Gaithersburg, Maryland, 2013. Available from:

<http://www.itl.nist.gov/div898/handbook/>. Access at: 08 oct. 2015.

NEGRÃO, J. H.; BALSEIRO, A.; FARIA, J. A. Uso de Laminados de Carbono Para Reforço e Reabilitação de Vigas de Madeira. In: CONGRESSO IBERO-LATINO AMERICANO DA MADEIRA NA CONSTRUÇÃO, 1., Coimbra, 2011. Anais... Coimbra: Universidade de Coimbra, 2011.

NEUBAUEROVÁ, P. Timber Beams

Strengthened by Carbon-Fiber Reinforced Lamellas, Procedia Engineering, v. 40, p. 292297, 2012.

ROSA, P.; ESCAMILLA, A. C.; GARCÍA, M. N. G. Bending Reinforcement of Timber Beams With Composite Carbon Fiber and Basalt Fiber Materials. Composites Part B Engineering, v. 55, p. 528-536, 2013.

RUBINI, L.; MORAES, P. D. Aderência à Madeira de Polímeros Reforçados Com Fibras de Carbono Sob Temperaturas Elevadas. Floresta e Ambiente, Rio de Janeiro, v. 19, n. 2, p. 236-242, 2012.
SCHOBER, K.-U. et al. FRP Reinforcement of Timber Structures. Construction and Building Materials, v. 97, p. 106-118, oct. 2015.

SERRA, M. C. G. Estudo da Aderência a Altas Temperaturas Entre Madeira e Materiais de Reforço. Coimbra, 2010. Dissertação (Mestrado Integrado em Engenharia Civil) - Faculdade de Ciências e Tecnologia, Universidade de Coimbra, Coimbra, 2010.

THÓRHALLSSON, E. R.; SNAEBJÖRNSSON, J. T. Basalt Fibers as Composite Material for Structural Elements. In: COST ACTION TU1207. NEXT GENERATION DESIGN GUIDELINES FOR COMPOSITES IN CONSTRUCTION, Budapest, 2017. Anais... Budapest: COST Action TU1207 End of Action Conference, 2017.

VALLUZZI, M. R. et al. Moisture and Temperature Influence on Biocomposites-toTimber Bonding. Advanced Materials Research, v. 778, p. 561-568, sep. 2013.

VALLUZZI, M. R. et al. Multi-Scale Characterization of Moisture and Thermal Cycle Effects on Composite-to-Timber Strengthening. Construction and Building Materials, v. 102, p. 1070-1083, jan. 2016.

VINSON, J. R.; SIERAKOWSKI, R. L. The Behavior of Structures Composed of Composite Materials. Norwell: Kluwer Academics Publishers, 1993.

WANG, Y. C.; WONG, P. M. H.; KODUR, V. Mechanical Properties of Fibre Reinforced Polymer Reinforcing Bars at Elevated Temperatures. In: SFPE/ASCE SPECIALTY CONFERENCE: DESIGNING STRUCTURES FOR FIRE, BALTIMORE, Baltimore, 2003. Proceedings... Baltimore: SFPE/ASCE, 2003.

YOUNG, S. A.; CLANCY, P. Compression Mechanical Properties of Wood at Temperatures Simulating Fire Conditions. Fire and Materials, v. 25, n. 3, p. 83-93, jul. 2001.

\section{Acknowledgements}

The authors thank Texiglass Company for fiberglass donation. Financial support from Scholarships for Scientific Initiation Program (PIBIC) from UFSC, as undergraduate scholarships, and National Council for Scientific and Technological Development (CNPq), for a research grant for the second author. 


\begin{abstract}
Ângela do Valle
Departamento de Engenharia Civil, Centro Tecnológico | Universidade Federal de Santa Catarina | Campus Universitário, Trindade | Florianopolis - SC - Brasil | CEP 88040-900 | Caixa Postal 476 | Tel.: (48) 3721-8540 | E-mail: angela.valle@ufsc.br
\end{abstract}

\title{
Poliana Dias de Moraes
}

Departamento de Engenharia Civil, Centro Tecnológico | Universidade Federal de Santa Catarina | Tel.: (48) 3721-9546 |

E-mail: poliana.moraes@ufsc.br

\section{Giancarlo Zibetti Mantovani}

Departamento de Engenharia Civil, Centro de Ciências Tecnológicas | Universidade do Estado de Santa Catarina | Rua Paulo Malschitzki, 200, Zona Industrial Norte | J oinville - SC - Brasil | CEP 89219-710| Tel.: (47) 3481-7936 | E-mail: gzmantovani@gmail.com

\section{Hudson Fagundes}

Departamento de Transportes da Prosul - Projetos, Supervisão e Planejamento Ltda. | Rua Capitão Augusto Vidal, 3593 | Palhoça - SC Brasil | CEP 88131-050 | Tel.: (48) 99954-9010 | E-mail: hudson_fagundes@hotmail.com

\section{Revista Ambiente Construído}

Associação Nacional de Tecnologia do Ambiente Construído

Av. Osvaldo Aranha, 99 - 3o andar, Centro

Porto Alegre - RS - Brasil

CEP $90035-190$

Telefone: +55 (51) 3308-4084

Fax: +55 (51) 3308-4054

www. seer. ufrgs. br/ ambienteconstruido

E-mail: ambienteconstruido@ufrgs.br

(c) (i) This is an open-access article distributed under the terms of the Creative Commons Attribution License. 